\title{
(Re)Configuring City Meanings: Historic and Contemporary Imaginations in the City of Kandy, Sri Lanka
}

\author{
Kapila Dharmasena Silva, University of Kansas, USA
}

\begin{abstract}
:
This paper discusses the changes that occur in the meanings that people associate with historic environments and the impact of such changes in historic preservation. Using the city of Kandy in Sri Lanka as a case study, I suggest that there should be a critical focus on the environmental meanings associated with historic places in preservation efforts. Such efforts should investigate and safeguard the collective relationship of iconic, linguistic, and behavioral attributes of the place. These attributes are vital in evoking environmental meanings that define the cultural significance and contemporary relevance of those places for continued preservation.
\end{abstract}

Keywords: Environmental Meanings, Historic Preservation; City of Kandy; Intangible Heritage

\section{Introduction}

Preserving historic environments is a means of protecting and maintaining the memory of places, events, and people of bygone times. Even though preserved monuments act as mnemonic props to continually evoke historic memories, it is questionable whether the monuments hold the same historic meanings for the present-day communities. Historic places were constructed for certain purposes based on the prevailing worldview and belief systems that may usually differ from the contemporary socio-cultural, political, and economic realities. What the historic places mean to people today determines the degree of public support their preservation receives. In historic preservation, achieving architectural authenticity of monuments - their original status in terms of materiality, form, and style - is relatively easy if the necessary historic documentation is available for either factual or conjectural restoration. Maintaining their symbolic authenticity - what those places meant to people historically - in the contemporary times is difficult as environmental meanings change in tandem with cultural changes. When historic monuments lose their original meanings and become mere artifacts representing ideals of a previous era, their very existence could be threatened by either commodification or by vandalism, which is in some cases fueled by political extremism. Identifying the meanings communities associate with their historic environments is an essential step towards successful heritage management.

In a theoretical framework for studying environmental meanings, Rapoport (1990) suggests three categories of environmental meanings - high-level meanings (sacred meanings such as concepts of sacrality, cosmological systems), middle-level meanings (social meanings, such as power, wealth, status, group identity, political ideologies), and low-level meanings (instrumental meanings or basic factual understanding of the world around). In the case of high-level meanings, Rapoport further hypothesizes that in any given case only a few

The International Journal of the Constructed Environments, 2(3), 2012: 13- 28. 
people know the high-level meanings even in traditional societies, and that in most presentday environments high-level meanings are likely to be absent, or at least relatively unimportant. Since the reason for preservation of historic places is their cultural and community significance, I argue that such significance comes primarily from the high-level and middle-level meanings embedded in historic places. This argument, therefore, questions whether historically sacred environments that are preserved still communicate such high-level meanings to its present-day communities and whether such meanings still keep the original message intact. This then poses a practical question as to how to manage the symbolic authenticity of historic places.

This paper investigates this issue of environmental meanings in historic places and its preservation implications, using the historic City of Kandy in Sri Lanka as an instrumental case for this analysis.

\section{Historic Imaginations of Kandy}

Located in the central hills in Sri Lanka, Kandy was the capital of the native monarchy when it fell to the British in 1815 and is now the administrative capital of the Central Province of the country (Fig. 01). In 1988, the historic core of the city was declared a UNESCO World Heritage site. This historic area contains the old royal palace, the Temple of the Tooth Relic of the Buddha, which was the palladium of the Sri Lankan kings, Malwatta and Asgiriya Buddhist monasteries, four shrine complexes (called Dēvāla) dedicated to the guardian deities of the country, and a man-made lake. In addition, many Buddhist temples and monuments lie beyond this historic core, which also form a part of the city's heritage.

James Duncan $(1989,1990)$ points out that historically the design of Kandy City and most aspects of its daily life revolved around the message of sacral supremacy of the king of Kandy. He names this particular form of kingship the Sakran model, which was based on Hindu and Buddhist cosmological belief systems. Within this model, the kingdom or the capital city of a king represents a cosmic city in which Śakra, the king of the gods, resides. This kingship model is based on two principal intertwined narratives and sub-narratives. In the first of these, the city of a king is 'the world of the gods.' This is conceived in the subnarrative of Mount Meru, the cosmic mountain that rises from the cosmic ocean, which is the city of Śakra and his thirty-two gods. In the second principal narrative, it is 'the world of the cakravarti (universal monarch),' which refers to the sub-narratives of the cakravarti's control over the whole world, his control over his kingdom, and, in the case of Kandy, the cities of the former hero-kings of Sri Lanka.

An elaborate list of iconic elements (buildings and landscape features), behavioral elements (rituals), and linguistic elements (legends, myths, and names) transformed Kandy into a cosmic city (Duncan 1990). Some of the most significant of these are still intact. Historically the city was imagined to be square-shaped, the shape of cosmic cities. The commoners and nobles lived in the western half of the city. The royal palace, the Temple, the four dèvāla, and the lake called Kiri Muhuda (Ocean of Milk or Cosmic Ocean in which the abode of Śakra is located) are located in the eastern half of the city (Fig. $02 \& 03$ ). The western part of the city was a microcosmic representation of the larger kingdom and the world beyond. The eastern segment, which is topographically higher than the western part of the city, represented the Cosmic Mountain. Two ornamental ramparts symbolized the waves of the Cosmic Ocean and the clouds gathering around the Cosmic Mountain (Fig. 04). In his

The International Journal of the Constructed Environments, 2(3), 2012: 13- 28. 
annual ritual procession, the king circumambulated the city reaffirming his authority over the city and the kingdom. This pageant, now known as the Äsala Perahära, is still celebrated annually in July/August in honor of the Relic and the city's guardian deities (Seneviratne 1978). The entire city form and the rituals were thus clear references to the role of the city as a world of a universal monarch and an abode of a divine ruler with his retinue of gods (Duncan 1990).

\section{Research Design}

City residents' knowledge of Kandy as a sacred cosmic landscape was investigated using a multiple-choice questionnaire. The questionnaire had 10 questions; some referring specifically to one of the two principal narratives while others referring to both narratives (Table 1). The responses for each question in turn referred to one or more sub-narratives (Tables 2). Questions referred to a particular feature, name, or event in the city and asked participants to choose from the provided responses. Response choices included related subnarrative(s) along with reference to some other cultural schemata that might have been represented by that feature, name or event. These other narratives were derived from the findings of the pilot studies, wherein I found that people seem to assign different meanings to city elements in Kandy (Table 2). The questionnaire, therefore, tested people's knowledge about the city's historic and contemporary meanings. One of the response choices was 'city/city feature in question represents nothing;' and it gave the option of refuting the claim that the city has any particular historic or current meanings. Participants were allowed to choose more than one response for any given question.

Nonetheless, the questions were not designed to test all meanings and their iconic, linguistic, and ritual representations that James Duncan identified. Instead they elicited knowledge around two principal narratives and their sub-narratives, and accordingly referred only to some selected landscape features, rituals, and metonyms that still exist and are highly effective in communicating those narratives. Furthermore, the questions were carefully ordered to avoid any influence on participants' responses. For example, the first and last questions elicited the meanings operating at the macro-level in relation to the entire city, while the questions in between investigated the meanings attached to specific city features and events. While the first question examined the meanings attributed to the entire city in more general terms, the last question referred to the specific narratives in more specific terms. This strategy - discussing city meanings in more general terms -avoided introducing respondents to specific narratives at the very inception, which could have otherwise influenced their answer choices for the subsequent questions.

Participants were selected with criterion-based, dichotomous-case selection and quota sampling procedures (Schensul et.al. 1999). They were divided into two groups, using the knowledge of these historic narratives as the defining criterion. It is assumed that some might know these historic meanings (Group A) while others might not know these meanings (Group B). Group A included monks from the two monasteries who had performed the rituals in the Temple, officials associated with the Temple and dēvāla, and academics and heritage managers who work in the preservation program of these monuments. It is assumed that these participants might have gained the knowledge of historic meanings through their ritual duties or professional work associated with the traditional institutions. Group B represented the rest of the population of Kandy. This large group was divided into subgroups based primarily on

The International Journal of the Constructed Environments, 2(3), 2012: 13- 28. 
the level of education, and then based on ethnic/religious affiliation and gender to represent the social diversity. A specific quota of respondents was selected from each subgroup. The total sample size was 39 informants $(\mathrm{n}=12$ Group A +27 Group B), identified through a chain-referral selection method (Schensul et.al. 1999).

In addition to this questionnaire, I interviewed participants to find out their opinions on the essential characteristics of the city, their most liked/disliked places in the city, and spatial/symbolic relationships between city features. These interview data were later analyzed alongside the data gathered through the questionnaire on historic meanings.

\section{Configuring Contemporary Imaginations of Kandy}

Of the 39 participants answering the questionnaire, seven of them or $18 \%$ knew the historic sacred meanings of the city as described in the preceding section. Out of the 12 participants from Group A (those who were supposed to know these meanings) only six of them knew these meanings; among them, only four knew these narratives completely. These six respondents included a Buddhist monk, 2 academics, and 3 preservationists. Two of them, an academic who had helped Duncan in his study and a preservationist, disagree with Duncan's interpretation of Kandy as a cosmic landscape.

Out of the 27 respondents in Group B, only one of them knew these historic scared meanings of the city. Her father, a school principal, had taught her about these meanings. As they both are tertiary-level educated residents of Kandy it is likely that there could be more people, perhaps with higher education, who know these meanings, and would certainly pass them on to the next generation. The percentage of those who would know the scared meanings of the city is difficult to determine from just one case. But it indicates that there could be some residents in Kandy who might know the city's sacred meanings.

A close analysis of the data indicates that even though $82 \%$ of the participants do not have a comprehensive and articulated understanding of the historic meanings that defined Kandy as a cosmic city, they do have a fragmented knowledge about some sub-narratives, and that this incomplete knowledge of those cultural schemata has nevertheless helped them to form some sort of narrative about the city as a sacred place (Table 1 presents the nature of this fragmented knowledge). This inference is supported four ways: first, by analyzing the selected responses that referred to historic meanings; second, by analyzing those that referred to other new meanings; third, by analyzing other interview data in which participants made reference to these new meanings; and finally, by showing how this fragmented knowledge of historic sacred meanings is transformed into the contemporary readings of the city meanings.

Let us begin with the first principal narrative that Kandy symbolizes 'the world of gods.' The first question inquired what Kandy symbolizes in general. While $74 \%$ of the participants confirmed it is a sacred place, $18 \%$ of them responded that it represents a 'city of gods.' On average, $46 \%$ of the answers for the first question considered the city as a 'heavenly place' or 'world of gods.' The last question inquires what Kandy symbolizes in particular: Only $5 \%$ of the respondents answered that it represents the city of Śakra. Meanwhile $72 \%$ of the participants maintained it represents a 'world of gods where the Sacred Tooth Relic resides.' Even the participants who knew the historic meanings of the city preferred this answer as the most appropriate depiction of the city. Twenty-six per cent of the participants, answering the seventh question, thought that the cloud-drift wall around the

The International Journal of the Constructed Environments, 2(3), 2012: 13- 28. 
palace/Temple complex is a device to symbolize that 'the Sacred Relic resides in the heavens.' In response to the eighth question that inquired what the two rectangular divisions in the city symbolized, $33 \%$ of the participants said that it indicates the 'sacred and profane sections of the city.' While answering other questions in the interviews, participants considered the eastern rectangle including the temples, the Lake, and Udawatta Forest Reserve a sacred area. Finally, answering the fifth question which inquires what the annual procession in Kandy may symbolize, $95 \%$ of the respondents considered that it represents 'a ritualistic worship in the honor of the Tooth Relic and the gods.'

This inference that Kandy symbolizes a 'world of gods where the Sacred Tooth Relic resides' is a widely-held cultural schema becomes even more convincing when we analyze what the non-Buddhist participants said. Eleven non-Buddhists - 05 Christians, 03 Hindus, and 03 Muslims - participated in answering the questionnaire. Sixty-four per cent of them considered Kandy a sacred place; $73 \%$ of them said that the annual procession represents 'a ritualistic worship in the honor of the Tooth Relic and the gods;' and 82\% of them believed that the city symbolizes 'the world of gods where the Sacred Tooth Relic resides.'

These answers indicate that participants indisputably consider Kandy to be a sacred landscape and that it represents a 'world of gods where the Sacred Tooth Relic resides.' While this view still confirms the historic narrative of the city as 'the world of gods,' it is no longer in relation to that specific allusion to 'City of Śakra.' For example, questions 2, 3, 4, 6 and 7 inquired about the particular sub-narratives that refer to the City of Śakra, i.e., the Cosmic Ocean, Śakra's palace on Mount Mandāra, the Cosmic Mountain, the heavenly Ganges, and the Celestial Rampart, respectively. The percentages of correct responses range from $05 \%$ $21 \%$, an insignificant result, confirming that the reference to Kandy as the City of Śakra is no longer very strong among the participants. The majority of them thought that the landscape features that represented those sub-narratives are mere decorative strategies used to make the city beautiful and are devoid of any specific symbolic content.

Thus, in the wake of the king who emulated Śakra, his supreme role has apparently been assigned to the Sacred Relic. For millennia, the Relic has affirmed the legitimacy of the monarchy and outlasted them all, including the British occupiers of the city. The Relic by itself not only makes Kandy a sacred place, but also validates any claim to continuing historic dimensions of sacrality into the present, and allegorically forms a cosmic axis which locates the city at the center of the world, assures its stability and allows it to serve as a conduit between the worlds of the humans and the gods. Thus, essentially the first principal narrative of the sacred meanings of historic Kandy is fairly intact: The city still represents "the cosmos in miniature with the profane (western) rectangle containing the citizens symbolizing the earth and the (eastern) sacred rectangle containing the Buddha and the gods, symbolizing the heaven (Duncan 1989, p.188)," although there is no divine king today.

This schema, in many forms, recurs through the responses given to other interview questions too, thus further supporting this inference. For instance, winding up the interviews participants were asked to briefly describe the "quintessential Kandy" as they 'feel' it. Many responded, saying that "it is where the Sacred Tooth Relic resides." One Buddhist monk said it is where "the living Buddha himself resides." Another participant considered that she is "fortunate to be born in Kandy, it is a karmic reward, as Kandy is where the Sacred Relic resides." Many thought that Kandy is "a very serene place;" "a place that makes you physically and mentally peaceful;" "a place that fills your heart with blissful, spiritually uplifting emotions;" and all these sensations were "caused by the presence of the gods and the

The International Journal of the Constructed Environments, 2(3), 2012: 13- 28. 
Sacred Relic (Buddha)." The underlying schema is quite clear: The quintessential Kandy is a sacred, blissful place (a heaven) where the Buddha (represented by the Sacred Relic) and his entourage of gods reside. One participant thought this factor makes Kandy "a unique city among the cities in the world."

Let us now investigate the second principal narrative, that Kandy represents the "world of cakravarti and hero-kings of Lanka.' Answering the first question that inquires what Kandy symbolizes in general, $31 \%$ of the participants thought that it represents 'the political and military power of the king of Kandy.' Answering the fifth question which inquires what the annual procession in Kandy symbolizes, $28 \%$ of the respondents thought that it represents 'an event that asserted the supreme power of the king and his claim to the throne;' $38 \%$ of responses indicated that, in addition to the former, it represents how the king in a ceremonial procession circumambulated the city (the microcosmic form of the macrocosmic kingdom) to demonstrate his claim to rule. Some of the respondents who thought that this annual festival symbolizes the 'ritualistic worship in the honor of the Tooth Relic and the gods' added that this event was held by the monarchs to produce rain for his kingdom by honoring and pleasing the gods. This idea actually refers to two sub-narratives at issue: it is a reference first to the king's 'power' to summon gods and thus his authority 'over the world,' and second, to the hero-kings of Lanka, whose duty was to ensure the welfare of their subjects, and, by this specific rain-making ritual, supporting the agriculture-based economy (Duncan 1990; Seneviratna 1999). These answers therefore indicate that the participants hold some form of a cultural schema that the city symbolized the 'world of a powerful king' - his authority over the capital, the kingdom, and the productive forces of the nature - and that he emulated the hero-kings of the country in performing his royal duties.

More evidence supports this inference. Question 2 inquired what the Lake symbolizes, and $22 \%$ of the participants thought that it represented 'king's ownership of all the water and natural resources of the country,' a reference to both 'the king's control over the kingdom' and 'the hero-kings' who traditionally held the ownership of the natural resources of the country. Some participants mentioned that it was the tradition for a king to build a reservoir to support the agricultural economy of the country, and thus the Lake represents this tradition. However, Kandy Lake was built simply for city beautification by the last king of Kandy. Question 9 asked what the city blocks symbolized; while 15\% of the participants answered that they represented various administrative units of the historic kingdom, $46 \%$ of the respondents thought that the city blocks represented areas where groups of people performing services to the court lived. Both answers are correct and showed that some participants knew the sub-narrative that the city was 'a microcosmic representation of the historic kingdom' both in social and spatial terms.

A new representative dimension of the sub-narrative that the city symbolizes 'the king's control over the kingdom' is evident from some of the responses given to the questions 2, 4, 6, and 7. Answering these questions that inquired about the symbolic content of the Lake, Udawatta Forest, the wave-swell wall, and the cloud-drift wall respectively, some participants had the opinion that these features were created for the defense of the city, the king, and the Sacred Relic. Historically, Udawatta Forest played a defense purpose: it was a forbidden forest guarded by a special regiment and its topography, thickets, and wild animals made it impenetrable (Karunaratna 1986). Other features lacked such an apparent strategic purpose (Duncan 1990). De Silva (1999) mentions that the selection of Kandy as the capital would have been influenced by its strategic importance for defense. Many of the locational

The International Journal of the Constructed Environments, 2(3), 2012: 13- 28. 
prerequisites for a strongly defended city as prescribed in the ancient texts on town planning were found in Kandy: it was protected by mountains, water ways, marshy lands, and thick forest covers. Indeed this was the argument proposed by one academic who disagrees with Duncan's postulation that Kandy represents a cosmic landscape. According to him, Kandy simply represented a strongly protected capital city and nothing more. Infusing historic facts with imaginations on ancient warfare and city planning, some participants tend to assign new meanings to the landscape, which nevertheless confirm the sub-narratives of the 'king's control over the kingdom' and the city's relation to that of 'the hero-kings of the country.'

Another reference to these sub-narratives can be found in an answer given to question 3 that inquired what the palace/temple complex, specifically its prominent octagonal structure, represented. Eighty-two per cent of the respondents said that 'the king used to make public appearances and address the nation' from there. Sixty-four per cent of the non-Buddhist participants believed so too. This is again a strong allusion to the sub-narratives of the 'king's control over the kingdom' and that the king emulated 'the hero-kings of the country.' It is true that the king gave audiences to his subjects from this specific place (Duncan 1990; Seneviratne 1999). Heads of the State in Sri Lanka still follow this tradition by addressing the nation from this octagonal structure after their election to public office, thus reenacting the traditional ritual and reinforcing the historic cultural schema, which in turn sends the message of their political control over the 'kingdom' (country) and their willingness to follow in the footsteps of the hero-kings of the nation (Duncan 1985, 1989; Seneviratna 1999). Thus the palace/temple complex and the city itself symbolize the country's rulers' control over it. Their association with the righteous practices of the historic monarchy is a powerful, lively, and widely-held cultural schema even today.

One of the response choices given to the final question specifically referred to a subnarrative of the Aśokan discourse of kingship: A righteous Buddhist monarch was considered to be a bodhisattva, a virtuous person striving to become a Buddha in the future. This was a well-believed cultural schema associated with the hero-kings of Sri Lanka (Duncan 1990). This response choice suggested that the city represented a 'heavenly city of a bodhisattva.' Only two respondents selected this choice. It is therefore difficult to determine whether the participants believed that there was any connection between this specific sub-narrative of hero-kings and the kings of Kandy.

In addition to selecting responses in the questionnaire, participants freely opined on what they thought Kandy represents. During the interview, 23\% of them added that Kandy represents a continuing tradition of capital cities of the hero-kings of the country: a sacred serene landscape that represented the political authority and pious rule of the monarchy, the socio-economic system based on agriculture, and simple lifestyle guided by the teachings of the Buddha. A similar opinion was given when answering the first question that inquired what Kandy generally embodies; $41 \%$ of the respondents thought that it represents a combination of these meanings.

This fragmented knowledge of the historic sacred meanings suggests that the participants believed that Kandy symbolizes 'the world of a powerful king, who followed the traditions of the hero-kings of the country.' For them, the city still epitomizes these traditional meanings of the political authority and connects the past, present, and the future. The monarchy is no more, yet the memory of the kings and their actions are revered and the city vividly invokes that powerful cultural schema. Thus, in essence, the second principal narrative of the historic sacred meanings of Kandy is still intact.

The International Journal of the Constructed Environments, 2(3), 2012: 13- 28. 
The contemporary schema of city meanings thus formed still retains its original coreconcepts: it is a sacred place, a 'world of gods where the Sacred Relic resides,' a 'world of a once powerful king' and a city that emulates 'the cities of the hero-kings of Lanka.'

\section{Preservation Implications of the Findings}

Under the UNESCO World Heritage Convention, the historic monuments located in the scared eastern quadrant in Kandy have been listed as World Heritage since 1988. I would argue that the success of the historic preservation program in Kandy is in part because of the city's historic meanings still exist today, though known to the people only in a fragmented manner, but considered relevant in the contemporary context. These monuments are highly regarded as religiously and historically important by the people, both locally and nationally, including the non-Buddhists in the city. The cultural institutions and historical memory these monuments represent have increasingly become politically important in contemporary Sri Lanka (Duncan 1985, 1989; Perera 1998). For the residents in Kandy, the sacrality of the monuments rendered the city an ideal place to live (Silva 2011). What these monuments symbolize, therefore, goes beyond mere economic value as tourist attractions and is relevant for the contemporary times in its social, cultural, and political dimensions. For the residents, seeing the city as a 'sacred place where the Sacred Relic resides and a city of hero-kings of the country' is a valid, timely, and a meaningful proposition. This perception consequently renders the preservation program a legitimate enterprise with tremendous social support guaranteeing the survival of the monuments and related cultural institutions. Most importantly, the transformations in the historic meanings were not drastic; the symbolic authenticity of the place is thus sufficiently continued into the present day. Not only the historic iconic forms, but also the linguistic and behavioral forms that signified these meanings still exist in Kandy in some form and that has helped preserve the symbolic authenticity of the city, even though preservation efforts have so far been focused merely on the physical authenticity of the monuments.

\section{Conclusion}

My findings suggest that Rapoport's hypothesis regarding the sacred meanings in present-day environments requires a slight modification. He states that in any given case only a few people know the high-level meanings even in traditional societies and that in most present-day environments high-level meanings are likely to be absent, or at least relatively unimportant. I argue that in any given case only a few people would have a comprehensive or complete knowledge of the high-level meanings in the environment, and a majority would know some aspects of these high-level meanings and that in some present-day environments high-level meanings could still be relatively important.

This study points to four important aspects that should be given attention in historic preservation programs. Firstly, the meanings associated with the monuments should be safeguarded as well in addition to the preservation of physical aspects of historic monuments. If local communities do not see any relevance in the historic monuments beyond their economic value as tourist destinations it becomes difficult to maintain historical authenticity of places, which is the primary task in preservation. Consequently studying the meanings and values people attribute to historic places, the dissonance between historic and contemporary

The International Journal of the Constructed Environments, 2(3), 2012: 13- 28. 
place meanings, the ways of transmitting these meanings across generations, and the ways of mitigating any negative aspects in meanings associated with historic places becomes imperative for successful historic preservation.

Secondly, attention should be paid to the role of linguistic and behavioral aspects associated with historic places in transmitting and continuing the intangible meanings across time and generations. In Kandy, the memory of iconic monuments were in fact preserved in the forms of myths, legends, and stories and communicated through daily and seasonal rituals, festivities, and arts and crafts traditions. These linguistic and behavioral aspects changed over time adjusting to the temporal realities and cultural change, but their survival in some form and continued association with the monuments helped preserve historic narratives of the place, even if in a fragmented manner. Furthermore, the survived historical narratives have transformed in a manner that is compatible with the present context. UNESCO's convention on Intangible Cultural Heritage has recognized the value of safeguarding oral traditions and cultural practices as part of cultural heritage (UNESCO 2003). However, their safeguard remains narrowly focused on such practices only. Their importance in the preservation of historic places and monuments has not gained wider attention yet. The theoretical framework Duncan (1990) developed for the study of historic Kandy should be useful to heritage managers seeking to identify symbiotic relationship of iconic, linguistic, and behavioral forms in defining cultural significance of historic landscapes.

Thirdly, effective heritage interpretation and community education is critical in preservation activity. As demonstrated in the case of Kandy, local communities' knowledge of the historical meanings of monuments as well as the meanings they currently associate with monuments may be imprecise and fragmented. Such understanding may not be widely shared and may change rapidly, even when historic meanings are relevant with a current sociocultural context. Careful reconstruction of meanings and informing local communities of the significance of place are essential for preservation success. This requires wider community participation and education.

Finally, historic preservation education should be a multi-disciplinary enterprise. The preceding three points demands special disciplinary training. Heritage managers require broader disciplinary understanding and professional assistance, especially by experts in the fields of anthropology, sociology, political science, and public education, in this connection.

The International Journal of the Constructed Environments, 2(3), 2012: 13- 28. 


\section{References}

De Silva, N. (1999). Architecture and chronology of the built environment of the historic hill capital of Kandy. In A. Seneviratna \& N. de Silva (Eds.), World heritage city of Kandy, Sri Lanka: Conservation and development plan (pp. 67-81). Colombo, Sri Lanka: Central Cultural Fund.

Duncan, J. S. (1985). Individual action and political power: A structuration perspective. In R.J. Johnston (Ed.). The Future of Geography (pp. 174-189). London: Methuen.

Duncan, J. S. (1989). The power of place in Kandy, Sri Lanka: 1780-1980. In J. A. Agnew \& J. S. Duncan (Eds.), The power of place: Bringing together geographical and sociological imaginations (pp. 185-201). Boston, MA: Unwin Hyman.

Duncan, J. S. (1990). The city as text: The politics of landscape interpretation in the Kandyan kingdom. Cambridge: University of Cambridge Press.

Karunaratna, N. (1986) Udawattakälē: The forbidden forest of the kings of Kandy. Colombo, Sri Lanka: Department of the National Archives.

Perera, N. (1998). Society and Space: Colonialism, nationalism, and postcolonial identity in Sri Lanka. Boulder, CO: Westview Press.

Rapoport, A. (1990). The meaning of the built environment: A nonverbal communication approach $\left(2^{\text {nd }}\right.$ ed.). Tucson, AZ: The University of Arizona Press.

Rohanadeera, M. (1998). Asgiriyen Udarata Ethihāsaya (History of Upcountry through Asgiriya). Battaramulla, Sri Lanka: Mendis Rohanadeera.

Schensul, S. L., Schensul, J. J., \& LeCompte, M. D. (1999). Ethnographer's Toolkit Series: Volume 2. Essential ethnographic methods: Observations, interviews, and questionnaires. Walnut Creek, CA: AltaMira Press.

Seneviratna, A. (1999). Socio-cultural heritage of Kandy. In A. Seneviratna \& N. de Silva (Eds.), World heritage city of Kandy, Sri Lanka: Conservation and development plan (pp. 3763). Colombo, Sri Lanka: Central Cultural Fund.

Seneviratne, H.L. (1978). Rituals of the Kandyan state. Cambridge, London: Cambridge University Press.

Silva, K. D. (2011). Mapping Meanings in the City Image: A Case Study of Kandy, Sri Lanka. Journal of Architectural \& Planning Research, 28 (3): pp. 229 - 251.

UNESCO (2003). The Convention for the Safeguard of the Intangible Cultural Heritage of the Humanity. Paris, France: UNESCO.

The International Journal of the Constructed Environments, 2(3), 2012: 13- 28. 


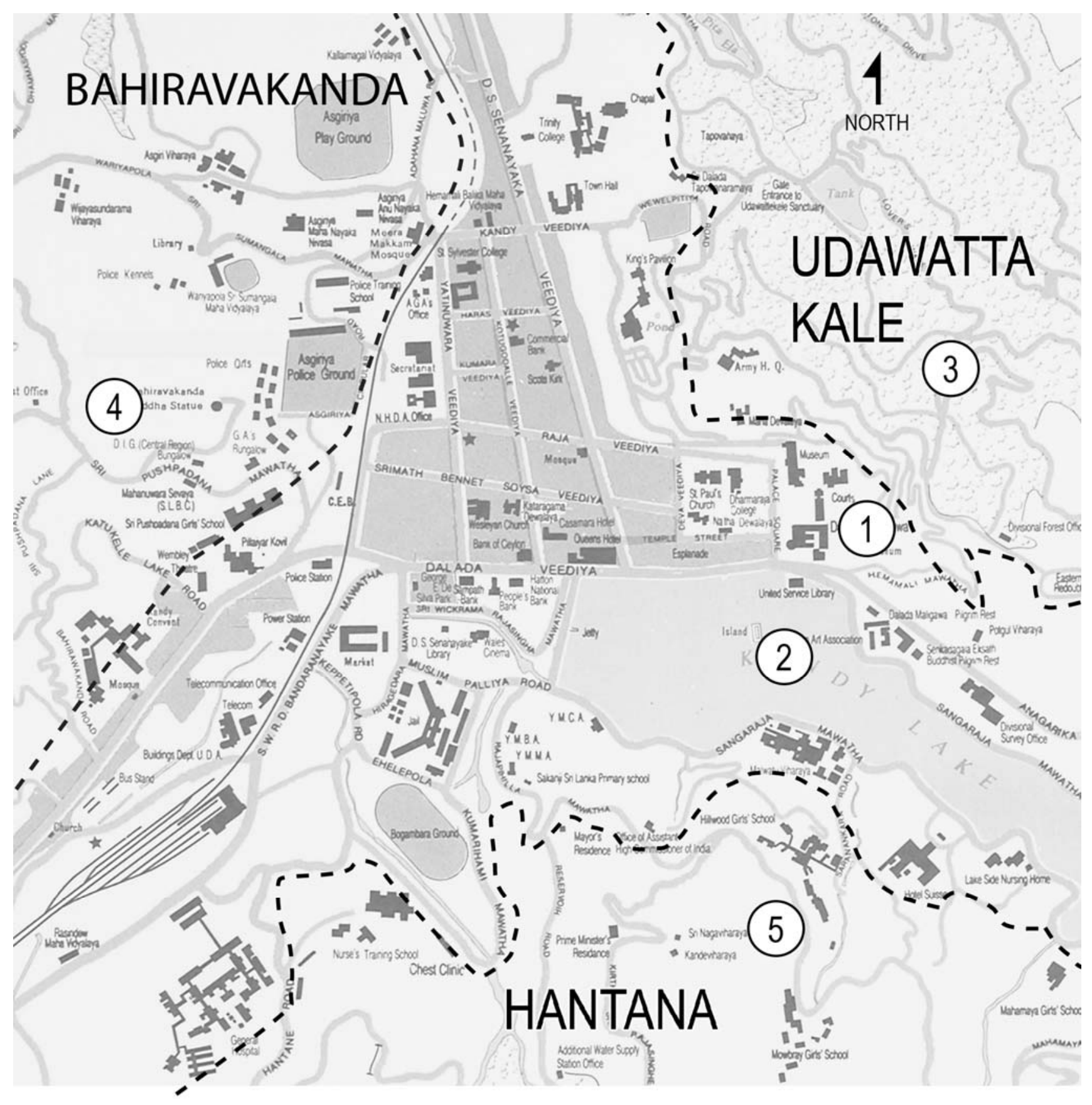

1 TEMPLE OF THE TOOTH RELIC

2 KANDY LAKE

3 UDAWATTA RANGE

4 BAHIRAVA KANDA RANGE

5 HANTANA RANGE

- - - RANGE BOUNDARY

Figure 01. Map of Downtown Kandy

The International Journal of the Constructed Environments, 2(3), 2012: 13- 28. 


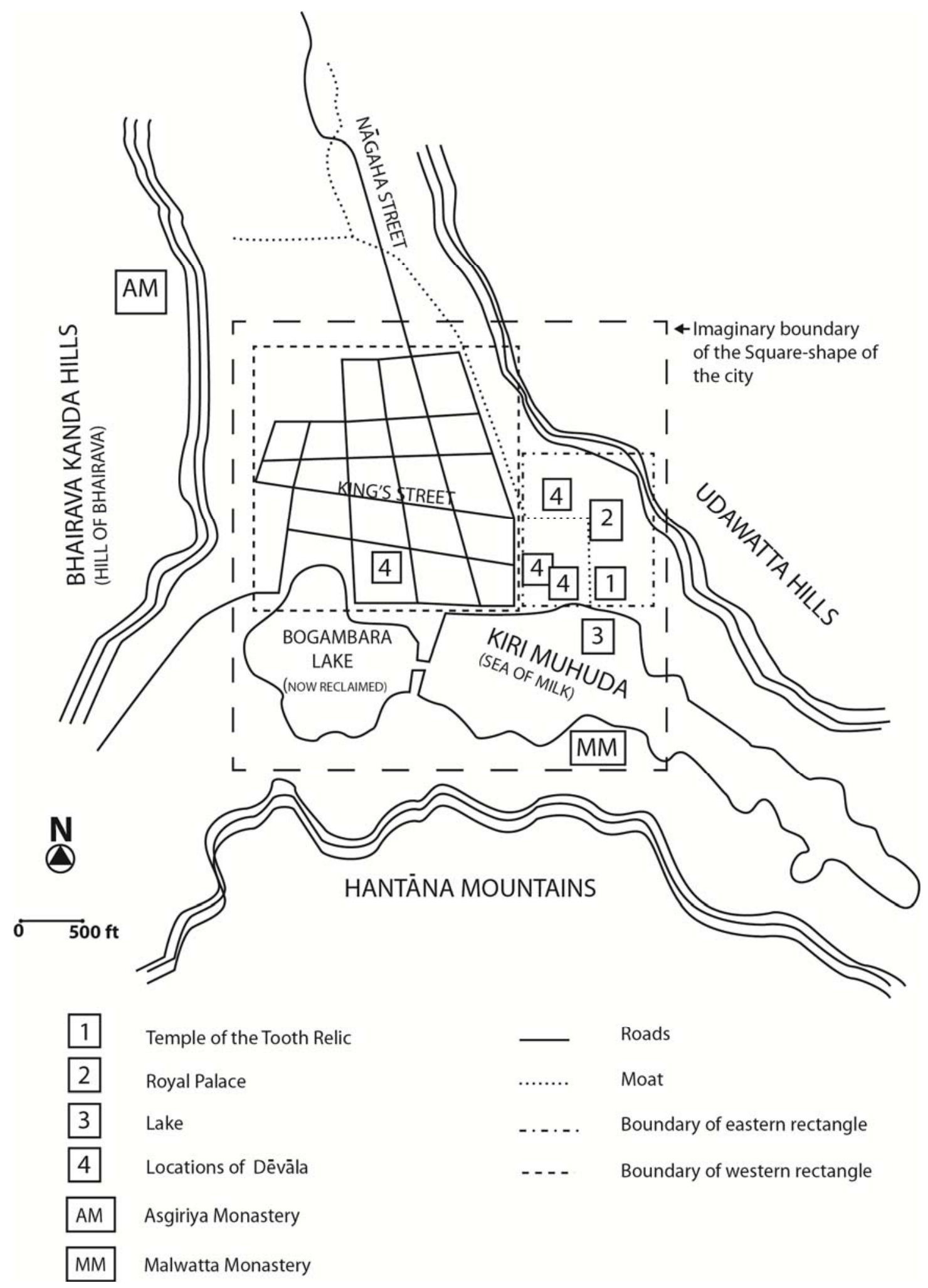

Figure 02. Sacred Urban Form of Historic Kandy (based on J. Duncan, 1990, p. 83)

The International Journal of the Constructed Environments, 2(3), 2012: 13- 28. 


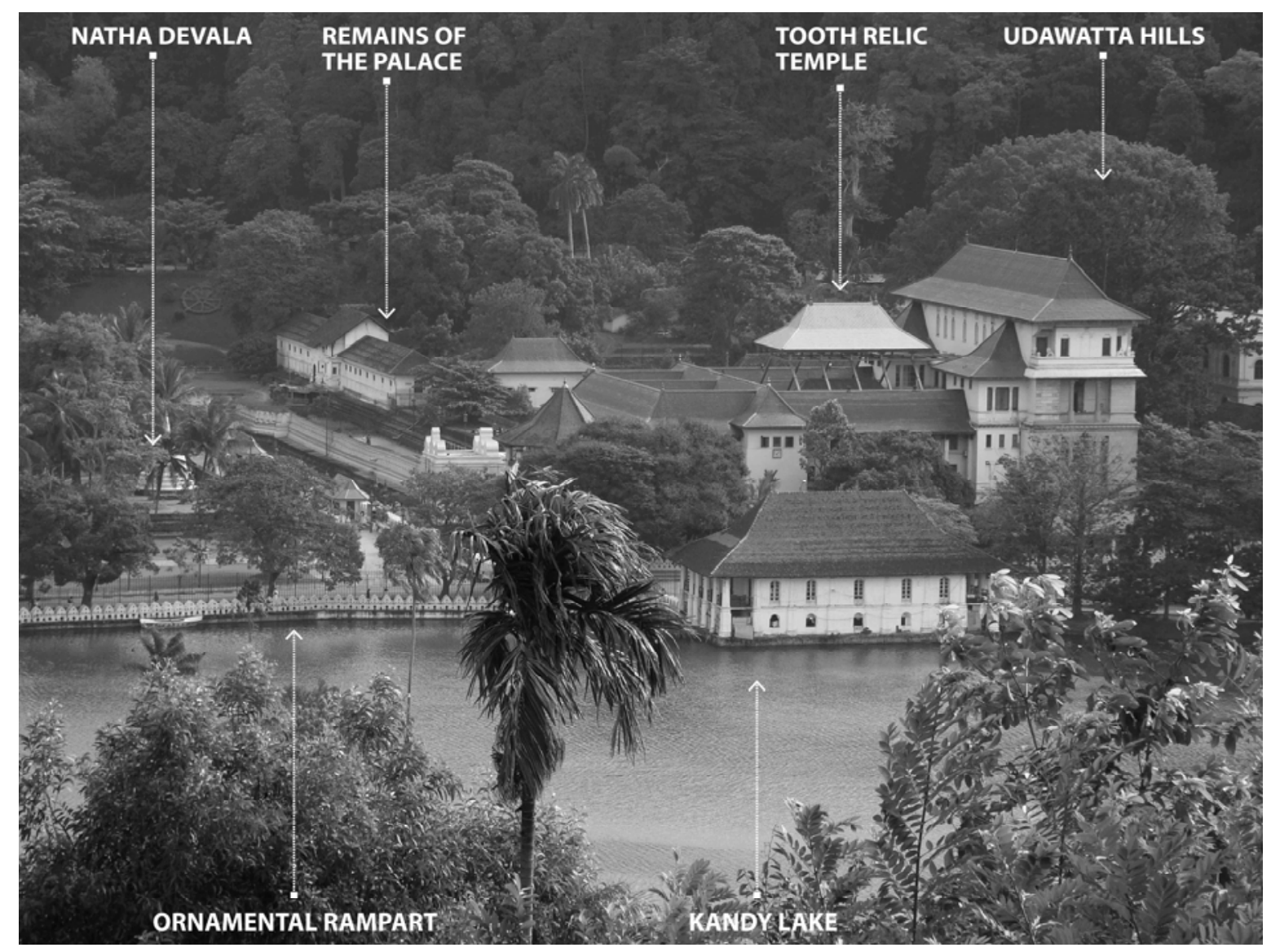

Figure 03. The Mount Mandāra (the Palace/Temple Complex) over the Cosmic Ocean (Kandy Lake) 


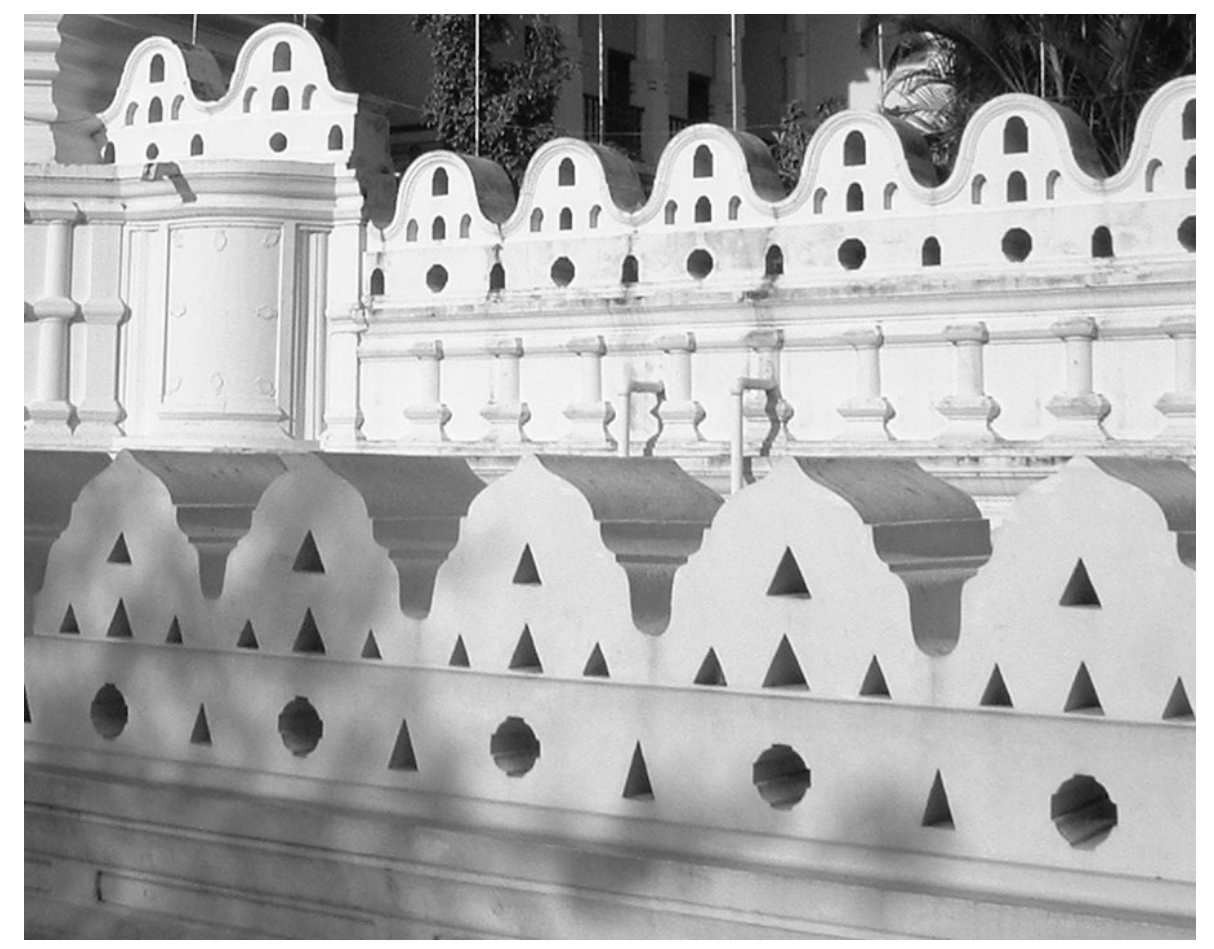

Figure 04. Ornamental Ramparts

(The Cloud-drift wall above the Wave-swell Wall) 


\begin{tabular}{|c|c|c|}
\hline Questions & Answer Choices & $\begin{array}{c}\% \text { of } \\
\text { selected } \\
\text { choices }\end{array}$ \\
\hline \multirow{5}{*}{$\begin{array}{l}\text { 1. Kandy City } \\
\text { represents; }\end{array}$} & (i) A sacred place & $74 \%$ \\
\hline & (ii) A place full of scenic beauty & $77 \%$ \\
\hline & (iii) The supreme political \& military power of kings & $31 \%$ \\
\hline & (iv) A city of gods & $18 \%$ \\
\hline & (v) It represents nothing & $03 \%$ \\
\hline \multirow{5}{*}{$\begin{array}{l}\text { 2. The Kandy Lake } \\
\text { represents; }\end{array}$} & (i) It represents nothing & $00 \%$ \\
\hline & (ii) The Cosmic Ocean of Milk around the City of Sakra & $15 \%$ \\
\hline & (iii) A device used to make the city beautiful & $92 \%$ \\
\hline & (iv) The king's control over the water \& natural resources & $22 \%$ \\
\hline & (v) The Sacred Anotatta Lake in the Himalayas & $03 \%$ \\
\hline \multirow{5}{*}{$\begin{array}{l}\text { 3. The Temple \& } \\
\text { Palace Complex, } \\
\text { especially the Octagon, } \\
\text { represents; }\end{array}$} & (i) From where the king gave public audience \& addressed the nation & $82 \%$ \\
\hline & (ii) The Vaijayantha Palace of Sakra on Mount Mandara & $21 \%$ \\
\hline & (iii) The Alakamanda Palace of God Kuvera & $00 \%$ \\
\hline & (iv) The Ghandha Kuti (perfumed eremitical cell) of the Buddha & $08 \%$ \\
\hline & (v) It represents nothing & $08 \%$ \\
\hline \multirow{5}{*}{$\begin{array}{l}\text { 4. The Udawatta } \\
\text { Forest Reserve } \\
\text { represents; }\end{array}$} & (i) The Cosmic Mountain Meru and the heavens above & $05 \%$ \\
\hline & (ii) The Himalayas & $10 \%$ \\
\hline & (iii) The forest cover around the historic Jetavana Monastery & $08 \%$ \\
\hline & (iv) The mountain where the Alakamanda Palace is located & $03 \%$ \\
\hline & (v) It represents nothing & $49 \%$ \\
\hline \multirow{5}{*}{$\begin{array}{l}\text { 5. The annual } \\
\text { procession in Kandy } \\
\text { represents; }\end{array}$} & (i) The supreme power of the king and his claim to the throne & $28 \%$ \\
\hline & (ii) How the king in a ceremonial procession circumambulated the city & $38 \%$ \\
\hline & (iii) A ritualistic worship in the honor of the Tooth Relic and the gods & $95 \%$ \\
\hline & (iv) A cultural pageant & $21 \%$ \\
\hline & (v) It represents nothing & $00 \%$ \\
\hline \multirow{5}{*}{$\begin{array}{l}\text { 6. The Wave Swell } \\
\text { Wall around the Lake } \\
\text { represents; }\end{array}$} & (i) The waves on the Lake & $23 \%$ \\
\hline & (ii) The waves on the Cosmic Ocean of Milk & $08 \%$ \\
\hline & (iii) The Fame of the King & $05 \%$ \\
\hline & (iv) The Fame of the Gods & $03 \%$ \\
\hline & (v) A device used to make the city beautiful & $82 \%$ \\
\hline \multirow{5}{*}{$\begin{array}{l}7 \text { 7. The Cloud Drift Wall } \\
\text { around the } \\
\text { palace/Temple } \\
\text { complex represents; }\end{array}$} & (i) A device used to make the city beautiful & $77 \%$ \\
\hline & (ii) Clouds around the Sakra's Palace on Mount Mandara & $10 \%$ \\
\hline & (iii) Clouds around the Alakamanda Palace & $00 \%$ \\
\hline & (iv) A device to symbolize that the Sacred Relic resides in the heavens & $26 \%$ \\
\hline & (v) It represents nothing & $10 \%$ \\
\hline \multirow{5}{*}{$\begin{array}{l}\text { 8. The historic Nagaha } \\
\text { Street divides the city } \\
\text { into two sections, } \\
\text { which represent; }\end{array}$} & (i) The Western and Eastern sections of the city & $26 \%$ \\
\hline & (ii) The sacred and profane sections of the city & $33 \%$ \\
\hline & (iii) The sections where the King and Citizens lived separately & $26 \%$ \\
\hline & (iv) The Northern and Southern sections of the city & $05 \%$ \\
\hline & (v) They represent nothing & $21 \%$ \\
\hline \multirow{5}{*}{$\begin{array}{l}\text { 9. The different city } \\
\text { blocks represent; }\end{array}$} & (i) Various administrative units of the historic kingdom & $15 \%$ \\
\hline & (ii) The lands owned by the Kandyan nobility & $10 \%$ \\
\hline & (iii) The lands owned by the Malvatta/Asgiriya Temples \& Devalas & $23 \%$ \\
\hline & (iv) Where the different groups who performed royal services lived & $46 \%$ \\
\hline & (v) They represent nothing & $13 \%$ \\
\hline \multirow{5}{*}{$\begin{array}{l}\text { 10. Kandy City } \\
\text { represents; }\end{array}$} & (i) The City of Sakra, as the King represents Sakra, the king of gods & $05 \%$ \\
\hline & (ii) The City of Kuvera, as the King represents Kuvera & $00 \%$ \\
\hline & (iii) A heavenly city of a bodhisattva, as the king was a bodhisattva & $05 \%$ \\
\hline & (iv) A world of gods where the Sacred Tooth Relic resides & $72 \%$ \\
\hline & (v) It represents nothing & $05 \%$ \\
\hline
\end{tabular}

The International Journal of the Constructed Environments, 2(3), 2012: 13- 28. 
Table 2. The relationship between the Narratives and the Questions and Choices given

\begin{tabular}{|l|l|c|c|c|c|c|c|c|c|c|c|}
\hline \multicolumn{2}{|c|}{ Narratives (based on Duncan 1990) } & \multicolumn{7}{|c|}{ Corresponding Questions \& Choices (given in Table 1) } \\
\hline Key-narratives & Sub-narratives & 01 & 02 & 03 & 04 & 05 & 06 & 07 & 08 & 09 & 10 \\
\hline $\begin{array}{l}\text { City as a world of } \\
\text { Gods }\end{array}$ & Abode of Sakra & i, iv & ii & ii & i & & ii & ii & i, ii & & i \\
\hline & Cosmic Ocean & & ii & & & & ii & & & & \\
\hline & Cosmic Mountain & & & ii & i & & ii & ii & & & \\
\hline $\begin{array}{l}\text { City as the world } \\
\text { of cakravarti }\end{array}$ & Control over the world & iii & & & & i & & & & & iii \\
\hline & Control over the kingdom & iii & iv & i & & i, ii & & & i, ii & i, iv & \\
\hline & Relation to hero-kings & iii & iv & & & i, ii & & & i, ii & iii \\
\hline
\end{tabular}

